International Journal of Linguistics, Literature and Translation

ISSN: 2617-0299 (Online); ISSN: 2708-0099 (Print)

DOI: $10.32996 / \mathrm{ijllt}$

Journal Homepage: www.al-kindipublisher.com/index.php/ijltt

\title{
Politeness in Social Justice Texts of the New Testament and Nahjul- Balagh
}

\author{
Riyadh Tariq Kadhim Al-Ameedi1 8 (D) Safa Naji Abd² 8 (D) \\ ${ }^{12}$ College of Education for Human Sciences Department of English, Iraq \\ $\triangle$ Corresponding Author: Riyadh Tariq Kadhim Al-Ameedi, E-mail: hum.riyadh.tareq@uobabylon.edu.iq
}

ARTICLE INFORMATION ABSTRACT

Received: June 11, 2021

Accepted: July 18, 2021

Volume: 4

Issue: 7

DOI: $10.32996 /$ ijllt.2021.4.7.18

\section{KEYWORDS}

Politeness maxims, social justice, the New Testament, Nahjul-

Balagha.
God sends prophets and messengers to make justice prevail on the planet and threaten oppressors who take people's rights away to humiliate them. Divine books given to prophets and messengers show how a just society can be built where people save their dignity and live a secured life. This study deal with politeness as a pragmatic strategy in such texts. The present study is going to analyze 16 texts in two religious resources. The theme of these texts deals with social justice in the New Testament and Nahjul-Balagha. The adopted model is that of Leech's (1983) politeness. It aims to find out the politeness maxims in the New Testament and Nahjul-Balagha of social justice texts. The study aims to reveal the similarities and differences in their implying politeness maxims.

\section{Introduction}

The aim of the current study is to find out the politeness maxims in certain social justice texts in the New Testament and NahjulBalagha. It also aims to reveal the similarities and differences in their employing politeness maxims in such texts. It is hypothesized that all politeness maxims are used in the social justice texts of the New Testament and Nahjul-Balagha, moreover, there are similarities and differences in using these maxims. The adopted model deals with Leech's maxims of politeness (1983). The current study deals with 16 texts. Eight texts represent the theme of social justice in the New Testament and the other deal with the same theme in the Nahjul- Balagha.

\section{Social Justice and Politeness}

This section presents a theoretical background of the notions of social justice and politeness as a pragmatic strategy.

\subsection{The Concept of 'Social Justice'}

Rothmund et al. (2016,p.275) recognize social justice as a property of the social and political system. It reflects two different states of affairs: the distribution of benefits and burdens in the account of principles of justice, and social justice relies on procedures, norms, and rules that control political decisions to sustain the basic rights and liberates within a society.

Social justice deals with the whole system of society, thus, it is more comprehensive than other forms of justice such as criminal in the sense that criminal justice is used to refer to the aspects of social justice that concerns violations of criminal law since the interests of the community require apprehension and punishment to those violators and procedural justice (Karim \& Karim, 2020,p. 106) as illustrated in the following verse of the New Testament "...he hath anointed me to preach the gospel to the poor; he hath sent me to heal the brokenhearted, to preach deliverance to the captives, and recovering of sight to the blind, to set at liberty them that are bruised" (Luke 4:18). Jesus (PBUH) in the previous verse states the purpose of his message which makes people live a dignified life by having food, liberty, and healthiness. Another example is taken from Nahjul-Balagha in which Imam Ali (PBUH) identifies the relations between people in

\section{K C AL-KINDI CENTER $\mathbf{R}$ D FOR RESEARCH AND} Your gateway to world-class research

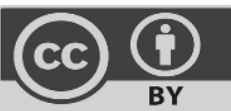

Published by Al-Kindi Center for Research and Development, London, United Kingdom. Copyright (c) the author(s). This open access article is distributed under a Creative Commons Attribution (CC-BY) 4.0 license 


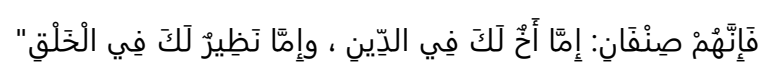

(Abda, 2004,p.572)

"They are of two kinds: either your brethren in religion or your likes in creation" (Al-Jibouri,2009, p.792). This token indicates equality between people, thus, people should not be discriminated against because of their religion, color, gender, race, and whatever.

\subsection{Politeness Principles}

Politeness has been studied as a pragmatic phenomenon in the theory of Leech (1983), Brown \& Levinson (1978), and many others. A speaker employs it to achieve different goals, for instance, promoting or maintaining harmonious relations (Thomas, 2013, p.1578).

This study uses Leech's theory. It identifies the ways that the callers of social justice have employed to achieve their purposes. Leech's maxims of politeness are introduced in terms of pragmatic scales:

i.The cost of benefit scale values how the action is assessed by the speaker to be beneficial or costly to the addressee.

ii. The optionality scale describes the degree to which the action is realized as the choice of the addressee.

iii. The indirectness scale describes the length of inference involved in the action.

iv. The authority scale estimates the degree of distance with respect to the poor or authority that one participant has over another.

v. The social distance, scale describes the degree of solidarity between the interlocutors (Félix-Brasdefer,2008,p.16).

Leech (1983,p. 133) presents six significant maxims to the politeness principles:

i. Tact Maxim can be seen in positive and commissive acts. The requirement of the maxims are the following: Minimize cost to the other and Maximize benefit to the other.

ii. Generosity Maxim comes in form of positive and commissive acts. It has two requirements: Minimizing the benefit to self and maximizing the costs to self.

iii. Modesty Maxim comes in the forms of expressive and assertive acts. It has two requirements: It minimizes the praise of self and it maximizes dispraise of self.

iv. Approbation Maxim can be seen in expressive and assertive acts. The requirements of this maxim are minimizing dispraise of other and maximizing praise of others.

v. Agreement Maxim has requirements of minimizing disagreement between self and other in addition to maximizing agreement between self and other.

vi. Sympathy Maxim can be seen in assertive. The requirements of the maxim are: Minimizing antipathy between self and other as well as maximizing sympathy between self and other.

These maxims are founded on assumptions regardless of culture, concept, and implementation. These maxims are universal and homogeneous. They are used to create verbal behavior to look after good relationships between the interlocutors (Song, 2012,p.23).

Wafa (2004,p. 261) states that politeness can be conducted by different means according to the social values of that society. More forms of showing awareness can be observed in society if it consists of different social and economic classes. Politeness is performed in Arabic by using plural forms to address the singular addressee. For instance,." "تفضلوا بتناول الطعام". The other way to be more polite can be conducted in a form as if the addressee is not present in that time of speech event as in

"يتفضل سيدي".

\section{The Model}

Fourteen texts will be analyzed according to Leech's model of politeness (1983). These texts deal with the theme of social justice in the New Testament and Nahjul- Balagha. Eight texts from each are chosen. The following figure sums up all the items of the model. 


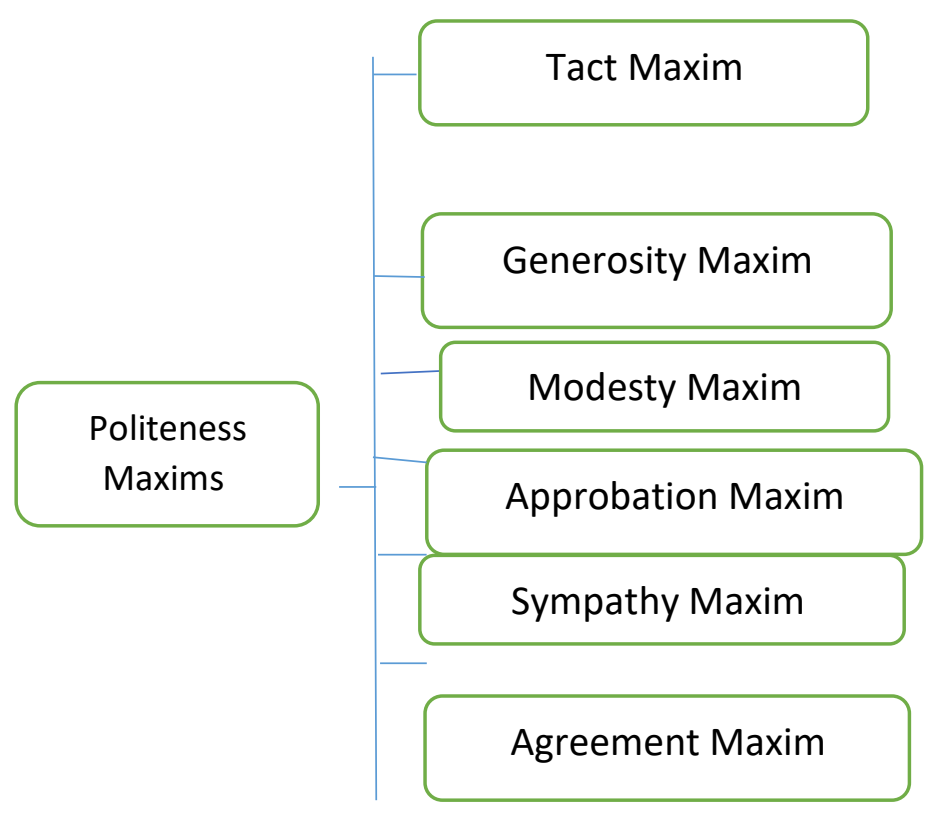

4. Data Analysis

4.1. Analysis of the New Testament Texts

Text 1

I pray, that your love may abound yet more and more in knowledge and [in] all judgment; That ye may approve things that are excellent; that ye may be sincere and without offense till the day of Christ; Being filled with the fruits of righteousness (King James Version, 2004, p. 677)

Tact maxim can be seen in his prayers. Paul minimizes the cost to others. He prays that they make a good decision to receive the fruit of justice. He asks God to grant them the knowledge to do their works in a correct manner. The improvement of their work cannot be done unless they have a good mind. People, who have deep knowledge, can sustain their relations with others since they cannot be deceived easily by their enemies. It is a tool that can save a person and the whole society from going astray. The significance of knowledge can be seen in Solomon's (PBUH) prayer in

"Give therefore thy servant an understanding heart to judge thy people, that I may discern between good and bad: for who is able to judge this thy so great a people?"(1 Kings 3:9)

The Prophet Solomon asks for knowledge to judge rightly. The oppressor is so ignorant that he does not realize the fact that he hurts himself before others. Paul asks God to make the addressees enjoy the sense of peace, fairness and maintain a good relationship between them.

Texts 2

Blessed [are] the meek: for they shall inherit the earth. Blessed [are] they which do hunger and thirst after righteousness: for they shall be filled. Blessed [are] the merciful: for they shall obtain mercy. Blessed [are] the pure in heart: for they shall see God. Blessed [are] the peacemakers: for they shall be called the children of God. Blessed [are] they which are persecuted for righteousness sake: for theirs is the kingdom of heaven. (King James Version, 2004, p.560)

Approbation maxim is observed in the text. The prophet blesses those who have patience, tender heart, and righteousness because he wants to encourage them to do more. He wants to relieve them by reminding them of the good consequences of their good works. Such thing can promote them to stand against oppression even if they might be killed since Jesus says "Blessed [are] they which are persecuted for righteousness sake: for theirs is the kingdom of heaven"

Text 3

But be not ye called Rabbi: for one is your Master, [even] Christ; and all ye are brethren. And call no [man] your father upon the earth: for one is your Father, which is in heaven. Neither be ye called masters: for one is your Master, [even] 
Christ. But he that is greatest among you shall be your servant. And whosoever shall exalt himself shall be abased. (King James Version, 2004, p.572).

Modesty maxim can be seen in the text. Jesus does not pay attention to his position as a prophet of God. He says no one is better than another. All people are equal since people come from one source. Thus, No one has the right to consider himself as better than another.

Jesus adheres to the approbation maxim. He maximizes the praise to a humble person because he seeks to serve others who are in need. But he breaches it on behalf of arrogant ones since they regard themselves to be better than others. Leaders should not discriminate between people. They should attempt to serve others and be humble as Jesus says in

"Ye call me Master and Lord: and ye say well; for so I am. If I then, [your] Lord and Master, have washed your feet; ye also ought to wash one another's feet. For I have given you an example, that ye should do as I have done to you." (John 13:13-15)

\section{Text 4}

Woe unto you, scribes and Pharisees, hypocrites! for ye devour widows' houses, and for a pretense make long prayer: therefore ye shall receive the greater damnation. Woe unto you, scribes and Pharisees, hypocrites! for ye compass sea and land to make one proselyte, and when he is made, ye make him twofold more the child of hell than yourselves. Even so, ye outwardly appear righteous unto men, but within ye are full of hypocrisy and iniquity. (King James Version, 2004,p.572)

Jesus's duty as a prophet of God is to defend the weak people. So, He breaches the approbation maxim to save people from hypocrites. They harm people because of their hypocrisy. A hypocrite is someone who looks like a good person to give a false impression. The prophet also breaches the tact maxim. He maximizes the cost to them in "therefore ye shall receive the greater damnation". He says that these kinds of priests have bad effects on other people. Thus, the destiny of those hypocrites is a terrible one. They contribute to destroying the personality of people. Therefore, they ruin society because of their false teachings. They are supposed to teach people how to enter paradise. But they mislead people. Leaders care more about their own importance than about God because their purpose is an earthly matter. Jesus clarifies obscurity things to people to be away from such leaders. He addresses the kinds of priests (Scribes and Pharisees) who are liars because they attempt to exploit weak people as widows to gain interests. He dispraises the false religious leaders. They are selfish people and they do not think about other's sufferings. He resists the oppression. The prophet puts his life in danger just to relieve oppressed people. Jesus breaches such maxim to save people from their effects.

\section{Text 5}

When thou makest a dinner or a supper, call not thy friends, nor thy brethren, neither thy kinsmen, nor [thy] rich neighbors; lest they also bid thee again, and a recompense be made thee. But when thou makest a feast, call the poor, the maimed, the lame, the blind: And thou shalt be blessed; for they cannot recompense thee: for thou shalt be recompensed at the resurrection of the just. (King James Version, 2004,p. 602)

Jesus wants to enhance ethical values in society. He wants them to take care of those kinds of people ("the poor, the maimed, the lame, the blind"). Generosity maxim is observed in Jesus's promise. He wants to benefit them more than they benefit from inviting their relatives through feeding the weak people.

\section{Text 6}

"There is neither Jew nor Greek, there is neither bond nor free, there is neither male nor female for ye is all one in Christ. Jesus." (King James Version, 2004, p.670)

Agreement maxim can be seen in the text among the members of the society between Jew and Greek, and male and female, and free and bound. He maximizes the agreement among them. He says that people should not be discriminated against because of barriers of nationality, gender, or rank in society. They are created by one God and they are followers of Jesus. So, People should work collectively to sustain society. So, mutual respect is needed to enforce the relationship among people within the community. Females are prohibited to participate in sacred ceremonies. But he says that there is no difference between females and males. Both have rights and responsibilities toward each other. They should work in partnership to develop their community. He calls for critical solidarity. He calls to respect the differences among people. 


\section{Text 7}

"Verily I say unto you, that this poor widow hath cast more in, than all they which have cast into the treasury: For all [they] did cast in of their abundance, but she of her want to be did cast in all that she had, [even] all her living" (King James Version,2004, p. 587)

The Prophet Jesus attempts to get the disciples' attention to her contribution. He wants them to see the imbalance case between her contributions and the rich's contribution although the rich give more than her. He says she gives the money that she needs for a living. So, she gives more than men. The sympathy maxim can be seen in the text. Jesus sympathizes with the widow. She gives money although she needs it for life. He wants to promote members of society to feel the suffering of others. The prophet breaches the tact maxim on behalf of a rich person. He finds out the contribution of the rich people as little if it compares to the contribution of the widow.

\section{Text 8}

If a brother or sister be naked and destitute of daily food, And one of you say unto them, Depart in peace, be ye warmed and filled; notwithstanding ye give them not those things which are needful to the body; what [doth it] profit? (King James Version, 2004, p.699)

James breaches the tact maxim through his rhetorical questions. These questions are used as a persuasive technique in the texts. James tries to convince people to look after the poor. He asks people to support them. Poor people do not have enough food to eat. They do not have clothes. They are cold and hungry. They need clothes and food. James calls the Inhabitants of society to love each other. They should look after those who are in need. They have a duty to give help when they can. Words do not apply a remedy. Instead, they depress further those who are in need of help. Good words are of no use. They are of no use if there is no action as well. James adheres to the generosity maxim on behalf of the poor because he maximizes the benefits to them.

\subsection{Analysis of Nahjul- Balagha Texts}

Text 1

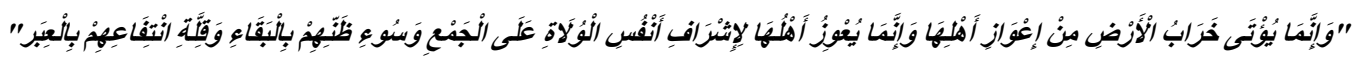

(Abda 2004, p.584)

"The ruin of the land is caused by the poverty of the cultivators, while the cultivators become poor when the officers concentrate on the collection (of money), having little hope for continuance (in their posts) and deriving no benefit from warnings."(Al-Jibouri, 2009,p.798-799)

Imam Ali breaches the approbation maxim. He dispraises the kind of rulers who care only about collecting money. They are busy because they save money for their benefit. They do not regard others' needs. He says that this kind will ruin the whole society. The Imam also says that the order of Allah is in

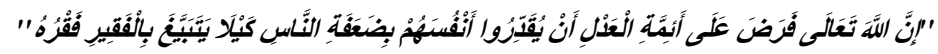

(Abda, 2004,p.440)

"Certainly, Allah, the Sublime, has made it obligatory on true leaders that they should maintain themselves at the level of low people so that the poor do not cry over their poverty."(Al-Jibouri, 2009, p.663)

Texts 2

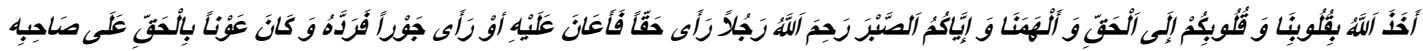

(Abda,2004,p.437)

May Allah keep our hearts and yours in righteousness, and may He grant us and yourselves endurance: "May Allah have mercy on the person who, when he sees the truth, supports it, when he sees falsehood, he rejects it and who helps the truth against anyone who is wrong." (Al-Jibouri, 2004, p.660)

Approbation maxim is seen in Imam Ali's pray. The imam asks Allah to send His blessings to the one who stands with just people. He asks people to support justice even if they will oppose his kinships. 
Text 3

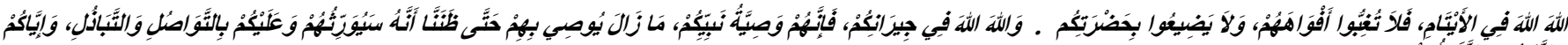

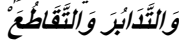

(Abda, 2004,p.565)

(Fear) Allah (and) keep Him in view with regard to orphans. So, do not allow them to starve, and they should not be ruined in your presence Fear) Allah (and) keep Him in view with regard to your neighbors because they were the subject of the Prophet's advice. He went on advising in their favor till we thought he would allow them to inherit them. You should maintain respect for kinship and spend on others. Avoid turning away from one another and severing mutual relations (Al-Jibouri, 2009, p.788).

Imam Ali uses intertextuality to make his speech more effective on the addressee. It is known that he has a tender spot in his heart for the poor, the orphans, and the oppressed. He is a kind friend to them. He is a sympathetic guide and a fellow sufferer. The imam encourages people to care for and support orphans. Thus, he adheres to the sympathy maxim because he recommends people to feel the suffering of orphans. If the orphan is neglected, he might have a bad personality. Then, he may harm himself and others as well. The needs of the orphan are designated in the following verse:

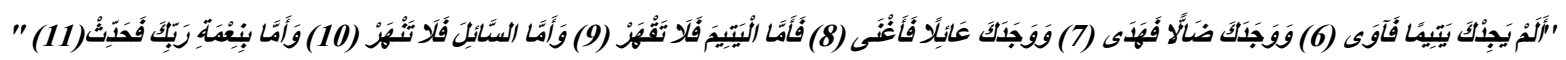

\section{The Morning Hours(الضحى) 6-11}

"Did He not find you an orphan and give you shelter? 7. And find you lost [that is, unrecognized by men] and guide [them to you]? And find you in want and make you be free from want? Therefore, as for the orphan, do not oppress [him]. And as for him who asks, do not chide [him], And as for the favor of your Lord, do announce [it]"(Shakir, 1999,p.307-8)

Thus, the orphan needs basic rights such as shelter, food, and the director. These needs should be provided by society to him. Otherwise, society may produce bad characters out of him. Imam Ali also breaches the tact maxim in his speech. He maximizes the cost to the addressee.

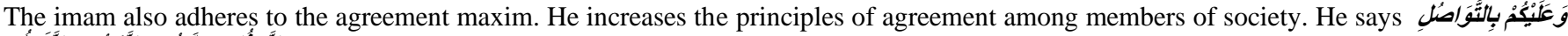
. This advice betters society. It also eradicates violence among the members. Allah observes the goodness in it. He says in

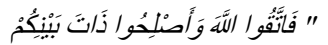

The Spoiles of War:1 (الانفال:1)

"So be careful of [your duty to] Allah and set aright matters of your Difference". (Shakir, 1999,p.78)

\section{Text 4}

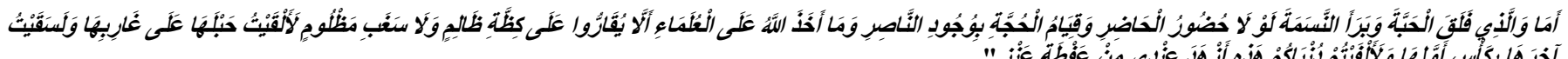

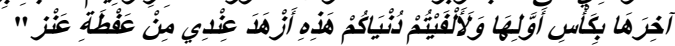

(Abda, 2004,p.56-7)

Behold, by Him who split the grain (to grow) and created living beings, if people had not come to me and supporters had not exhausted the argument and if there had been no pledge of Allah with the learned to the effect that they should no acquiesce in the gluttony of the oppressor and the hunger of the oppressed, I would have cast the rope of Caliphate on its own shoulders and would have given the last one the same treatment as to the first one. Then you would have seen that in my view this world of yours is not better than the sneezing of a goat. (Al-Jibouri, 2009,p.316)

The maxim of generosity is observed in the text since Imam Ali takes others' needs into his account, he does whatever he can do to relieve the oppressed people. Imam Ali wants to say that he has no desire for being Califia. Allah orders his believers (particularly religious scholars) to resist oppression. And, it is unlawful to help the oppressor. Some people may help the oppressor when they see his wrongdoing and they keep silent. Both the actual oppressor and the people who aid him have the responsibility for the injustice act. Allah does not consider it permissible for anyone to remain an idle spectator in a society divided into two classes of oppressed and oppressors, one suffers the pangs of hunger and the other well-fed and uneasy with the discomforts of over-eating. Thus, Imam Ali carried this heavy responsibility to help oppressed people. 


\section{Text 5}

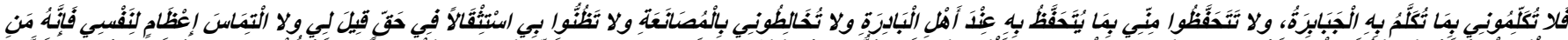

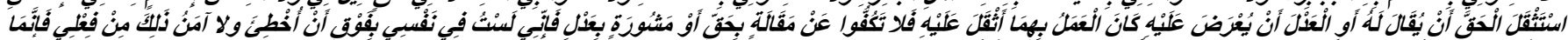
(Abda, 2004,p.523)

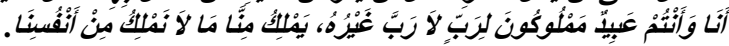

Do not shun me as the people of passion are (to be) shunned. Do not meet me with flattery, and do not think that I shall take it ill if a true thing is said to me because the person who feels disgusted when he hears the truth or a just matter is placed before him, would find it more difficult to act upon them. Therefore, do not abstain from saying the truth or pointing out a matter of justice because I other Lord. He do not regard myself to be above erring. Certainly, I and you are slaves owned by Allah, besides Whom there is no owns our souls which we do not own. (Al-Jibouri, 2009,p.680)

Imam Ali adheres to the tact maxim. He attempts to reduce the cost to inhabitants of society. He wants to take others' views to guide the inhabitants of society to the best ways that they can better their ways of living. The maxim of modesty can be seen in the text. Imam Ali has seen himself as an ordinary person. He does not think that he is better than another because he is a leader. The imam uses these maxims to point out that the just governor should regard himself as a person who commits mistakes. He should not be proud and arrogant because he has the authority and power.

\section{Text 6}

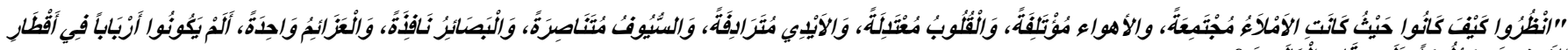

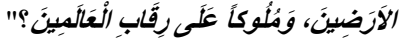

\section{(Abda, 2004,p.407)}

"See how they were when their groups were united, their views were unanimous, their hearts were moderate, their hands used to help one another, their swords were intended for assisting one another, their visions were sharp, and their aims were uniform. Did they not become masters of the corners of earth and rulers over the necks of all the worlds?"(Al-Jibouri, 2009,p.631)

The agreement maxim can be noticed in the text. Imam Ali attempts to maximize agreement among the members of the society. He encourages them to work in cooperation. Consequently, they can have a dignified life. The imam presents a good description of the people who preceded them. He says their unity gives them the advantage to be the rulers of the earth.

\section{Text 7}

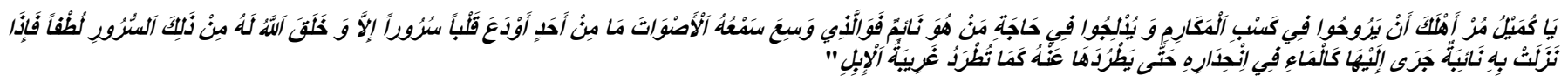

(Abda, 2004,p.680)

O Kumayl! Direct your people to go out in the day to achieve noble traits and to go out in the night to meet the needs of those who might be sleeping, for I swear by the One Whose hearing extends to all voices, if someone pleases another's heart, Allah will create a special thing out of this pleasing so that whenever any hardship befalls him, it will come running like flowing water and drive away from the hardship as wild camels are driven away (Al-Jibouri, 2009, p.879).

Imam Ali adheres to the generosity maxim. He maximizes the benefits to the needy and the helper people to enhance the intention of helping others inside the addressee. He puts the bases that enable people to be unified with others. Imam Ali says that Allah will help the kind people, who help others, in their calamities till the calamity will be removed. Their calamities will remove quickly as the force of water flows in his passing.

\section{Text 8}

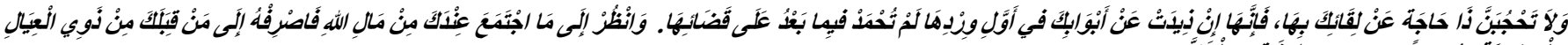

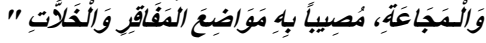

(Abda 2004,p.613)

"Do not prevent any needy person from meeting you because of the needy is returned unsatisfied from your door in the first instance, even doing it thereafter will not bring you praise. See what has been levied with you of the funds of Allah (in the public treasury) and spend it over the persons who have families, the distressed, the starving, the naked, at your end" ( Al-Jiboui, 2009, p.821).

Imam Ali breaches tact maxim. He maximizes the cost to the addressee. He asks him to take care of poor people. Qutham ibn alAbbas should decrease the social imbalance among members of society. The imam says such a thing (taking care of members of society) to enhance the relationship between inhabitants of society and their leaders. 


\section{Results of Analysis}

The following tables summarize the findings of the deployment of politeness maxims in social justice texts in the New Testament first and in Nahjul- Balagha second.

Table (5.1) Results of Politeness Maxims in the New Testament and Nahjul -Balagha

\begin{tabular}{|l|l|l|l|l|}
\hline \multirow{2}{*}{ Politeness Maxims } & \multicolumn{2}{l|}{ The New Testament Texts } & \multicolumn{2}{l|}{ Nahjul-Balagha Texts } \\
\cline { 2 - 5 } & Frequency & Percentage $\%$ & Frequency & Percentage\% \\
\hline Tact & 1 & 12.5 & 2 & 22.22 \\
\hline Generosity & 2 & 25 & 2 & 22.22 \\
\hline Modesty & 1 & 12.5 & 1 & 11.11 \\
\hline Approbation & 2 & 25 & 1 & 11.11 \\
\hline Agreement & 1 & 12.5 & 2 & 22.22 \\
\hline Sympathy & 1 & 12.5 & 1 & 11.11 \\
\hline Total & 8 & 100 & 9 & 99.99 \\
\hline
\end{tabular}

Table (5.2) Results of Violations of Politeness Maxims in the New Testament and Nahjul- Balagha

\begin{tabular}{|l|l|l|l|l|}
\hline \multirow{2}{*}{ Violation of Politeness Maxims } & \multicolumn{2}{|l|}{ The New Testament Texts } & \multicolumn{2}{l|}{ Nahjul-Balagha Texts } \\
\cline { 2 - 5 } & Frequency & Percentage \% & Frequency & Percentage \% \\
\hline Tact & 3 & 60 & 2 & 66.66 \\
\hline Approbation & 2 & 40 & 1 & 33.33 \\
\hline Total & 5 & 100 & 3 & 99.99 \\
\hline
\end{tabular}

\section{Conclusion}

The pragmatic study of the selected texts displays that the New Testament and Nahjul-Balagha carry the theme of social justice from similar perspectives. Both display that all people (leaders or ordinary people) are addressed all over the centuries and societies in a broader context. These divine resources involve messages which have the moral effects that they help to eradicate man's wicked behavior and transform him into a just one. These messages are valuable to create a society in which everyone receives genuine equality, fairness, and respect. They call for a virtual society that can be placed upon moral ethics, educational rules, and behaviors. In addition, They state man's duty toward others. Both assure that Allah seeks to secure the rights of people. They encourage people to forgive if the persons exceed their limits with them to sustain peace in society. They also state that Allah does not accept repentance unless the harmed person forgives the guilty for his exceedances.

All politeness maxims are employed throughout the selected texts of social justice as tact, generosity, modesty, approbation, agreement, and sympathy. Callers of social justice (Jesus, disciples, and Imam Ali) adhere to politeness maxims in the selected texts to achieve their purposes as enhancing unity in society, encouraging people to exert more efforts to help the weak, feeling the suffering of others, and minimizing the cost to the oppressed people. They also breach the approbation maxim to reform the personality of the corruptors. The tact maxims are breached in some texts in the New Testament and Nahjul-Balagha to save the dignity of the poor. Politeness maxims are breached to reform the personality of the addressee. They are also breached to guide the addressee in the right direction to manage his life.

The differences are seen in frequency and percentage of deployment of these maxims: Approbation and generosity maxims are seen for $25 \%$ in English texts. Thus, they are utilized in the New Testament more than Nahjul- Balagha. The tact maxim is utilized in Arabic texts more than English ones. It scores $22.22 \%$ and marks $12.5 \%$ in the New Testament. Imam Ali employs agreement maxim more than the New Testament. Approbation and tact maxims are breached in some texts. Approbation is breached in the New Testament more than Nahjul-Balagha. It marks 40\%. The tact maxim is breached in Nahjul-Balagha more than in The New Testament since it marks $66.66 \%$.

The study is limited to two texts that are concerned with the idea of social justice in the New Testament (which is a collection of Christian texts) and Nahjul- Balagha (which is a collection of sermons and narrations ascribed to Imam Ali, PBUH).

The study benefits students and scholars who are interested in contrastive pragmatics, textbook design, politics, and religious texts. They can make use of it to develop their studies. Further suggestions can be conducted by applying other linguistic approaches to social justice in religious contexts. 


\section{References}

[1] Abda, M. (2004). Nahjul-Balagha.Nasayih Al-Sinih

[2] Al-Jibouri, Y. T. (2009). Peak of Eloquence Nahjul-Balagha. Elmhurst, New York: Tahrike Tarsile Qur" an.

[3] Brown, P., \& Levinson, S. C. (1978). Universals in language usage: Politeness phenomena. In Questions and politeness: Strategies in social interaction (pp. 56-311). Cambridge University Press.

[4] Félix-Brasdefer, J., \& Cesar, M (2008). Politeness in Mexico and the United States: A Contrastive Study of the Realization and Perception of Refusals. John Benjamins Publishing Company.

[5] Karim, F., \& Karim, S. (2020). Access to Justice in Pakistan. Pakistan Law house.

[6] Leech, N. G. (1983). Principles of Pragmatics. Longman.

[7] Rothmund, T, Julia C. B., \& John T. (2016). The Psychology of Social Justice in Political Thought and Action. (pp. 275-293). In M. Schmitt, C. Sabbagh. In C. Sabbagh \&M. Schmitt(Eds). Handbook of Social Justice Theory and Research. Springer https://doi.org/10.1007/978-1-49393216-0 15

[8] Shakir, M. (1999). The Holy Quran (Koran). Tahrike Tarsile Qur'an.

[9] Song, S. (2012). Politeness and Culture in Second Language Acquisition. Palgrave Macmillan. The King James Version of the Holy Bible. (2004). http://www.davince.com/bible

[10] Thomas, J. (2013). Meaning in Interaction: An Introduction to Pragmatics. Routledge.

[11] Wafa, A., \& Abd W. (2004). Linguistics. Nahdah Misr 